\title{
Effect of Corporate Governance on Earnings Management of Commercial Banks in Nigeria
}

\section{Ubesie Madubuko Cyril Phd, Inyiama Ethel Chinakpude}

Department of Accountancy, Enugu State University of Science and Technology, Enugu, Nigeria

Email address:

www.ubesiemadubuko@yahoo.com (U. M. C. Phd)

\section{To cite this article:}

Ubesie Madubuko Cyril Phd, Inyiama Ethel Chinakpude. Effect of Corporate Governance on Earnings Management of Commercial Banks in Nigeria. International Journal of Accounting, Finance and Risk Management. Vol. 4, No. 2, 2019, pp. 61-70. doi: $10.11648 /$ j.ijafrm.20190402.13

Received: March 21, 2019; Accepted: May 6, 2019; Published: July 24, 2019

\begin{abstract}
The research examines the effects, magnitude and strength of the relationships between corporate governance and earning management of commercial banks in Nigeria. The research made use of secondary data obtained from annual report and accounts of four commercial banks, First Bank of Nigeria Plc, Zenith Bank Plc, Diamond Bank Plc and United Bank for Africa, from year 2007 to 2017. The nature and magnitude of association between the dependent variable (DPS) and the independent variables were determined using the multiple regression model. The movement pattern of the dependent and independent variable was represented graphically while descriptive statistics was used to check the validity of the result and data. Correlation Analysis was performed to test the strength of the relationship between selected variables. Earnings Per Share was found to be negatively and significantly influenced by Board Size (BDSIZE) while Ownership concentration has a positive and insignificant effect on Earnings Per Share. Board meeting has a positive and significant effect on Earnings Per Share. In line with the agency theory and consistent with the findings, it is implied thatOwnership Concentration and Board Meetingsclosely monitored and improved on as they have positive influence on Earnings Per Share.
\end{abstract}

Keywords: Corporate Governance, Nigerian Banks, Agency Theory, Earnings Management

\section{Introduction}

\subsection{Background of the Study}

The rot in the financial system accumulated over the years resulting from insider abuses, poor corporate governance, inefficiencies, etc, andfear of the collapse ofthefinancial system (and by extensionthe entire economy), made the apex bank, with the support of the Federal Government, to start a wave of consolidation in the banking industry, setting the minimum capitalbase of each bankatN25 billion (and shrinking the number of banks from 89 to 25 after a series of mergers and acquisitions) with the aim that the banks would become robust enough to act as agent/catalyst of economic growth and development functioning in line withhealthier andmore prudent modus operandi [1].

Banks governance is subject of particular importance and challenges due to the role of banks in economy and the current regulatory environment [2]. The bank corporate governance process is a complex framework. This governance framework encompasses a bank's stockholders, its managers and other employees, and the board of directors. Banks further operate under a unique system of public oversight in the form of bank supervisors and a comprehensive body of banking laws and regulations. The interaction between all of these elements determines how well the performance of a bank will satisfy the desires of its stockholders, while also complying with public objectives. For investors and regulators, this bank corporate governance framework is thus of critical importance in a bank's success and its daily operations.

Corporate governance is all about running an organization in a way that guarantees that its owners as stakeholders are receiving a fair return on their investment. It refers to the process through which an organization is governed and controlled. Clarkson and Deck opine that corporate governance is the process of a virtuous circle that links the shareholders to the board, to the management, to the staff, to the customer and to the community at large [3]. They argued that a company is a separate legal entity which no one 
actually owns. It therefore means that shareholders do not actually own a company [4].

As a concept, corporate governance connotes the processes involved in the discharge of the mandate of governance in corporate entities [5]. Adeolasubmits that corporate governance codes define the relationship between company management, their boards and their shareholders as well as require that management and directors carry out their duties within a framework of accountability and transparency [6].

Corporate governance has become a topical issue because of its immense contributions to the growth of modern economies where the private sector plays a key role in the growth process. Absence of good corporate governance is often blamed for the woeful performance of business entities. Developed private sectordriven economies with history of established corporate governance structures consistently record high and predictable earnings growth. Thus low economic growth rates that characterize developing nations areoften attributed to low level of corporategovernance practices in these economies. Anya opines that although corporate governance has attracted a great deal of public interest in recent times dueto its importance for the economic health of corporations and society, the concept is rather poorly defined globally since it covers a large number of distinct economic phenomena [7].

Different individuals have explained corporate governance according to their own perception or interest. Notable among them include: Wolfensohn cited by Anya who asserts that corporate governance is about promoting corporate fairness, transparency and accountability $[8,7]$. Dyckconceptualizes it as the ability of the outsiders (shareholders, non-executive directors and other stakeholders) to curtail the grabbing hands of the insiders (directors and managers) [9]. Shleifer and Vishny see corporate governance as a concept by which the suppliers of finance to corporations assure themselves of getting a return on their investments [10].

\subsection{Statement of the Problem}

There is substantial evidence of a positive link between firm performance and corporate governance. However, notwithstanding the avalanche of empirical support for positive effect of corporate governance on firm performance, some studies found negative or no relationship between corporate governance and profitability.

For the financial industry, the retention of public confidence through the enthronement of good corporate governance remains of utmost importance given the role of the industry in the mobilization of funds, the allocation of credit to the needy sectors of the economy, the payment and settlement system and the implementation of monetary policy. The banking industry consolidation posed additional corporate governance challenges arising from integration of processes, information technology and culture. Research had shown that two-thirds of mergers, world-wide, fail due to inability to integrate personnel and systems as well as due to irreconcilable differences in corporate culture and management, resulting in board and management squabbles.
In addition, the emergence of mega banks in the post consolidation era is a task on the skills and competencies of boards and managements in improving shareholder values and in balancing same against other stakeholder interests in the highly competitive banking environment.

Subsequent to a host of corporate corruption scandals, boards of directors are facing amplified pressure from investors, creditors and shareholders in a bid to ensuring effective corporate governance of their investments. In the rapidly growing economy of Nigeria, as in many other emerging markets, the banks are set to play a crucial role. It is, therefore, important to understand the key ingredients earnings management of banks. Bank's board members and executives have been subject to criminal and civil actions over hidden debt, inflated earnings, insider trading, tax evasion, misuse of funds, and breaches of fiduciary duties.

However, since the level of success recorded by any bank revolves around the effectiveness of the board of directors, it becomes very important to determine the nature, level of influence and pattern of the relationship that exist between these board characteristics and earnings management of commercial banks. Hence, the variable that may constitute the yardsticks by which corporate governance can be measured in the banking industry revolves around the structure of theboard of directors and the concentration of ownership.

Sequel to this, the study aims at evaluating the effects of Corporate Governance, such as Board Size, Ownership Concentration, and BoardMeeting on earnings management of commercial banks in Nigeria. The study ascertained the direction anddegree of relationship that existed between board characteristics and earnings managementof banks.

\subsection{Objectives of the Study}

The general objective of this study is to ascertain the effect of corporate governance on earnings management of commercial banks in Nigeria. In order to achieve the above stated objective, the following specific objectives were developed:

1. To determine the effect of board size on earnings per share of commercial banks in Nigeria.

2. To assess the effect of ownership concentrationon earnings per share of commercialbanks in Nigeria.

3. To evaluate the effect of board meetings on earnings per share ofcommercialbanks in Nigeria.

\subsection{Research Questions}

In line with the statement of objective and research problem above stated the following research questions will serve as a guide to the discussions in this work:

1. To what extent doesboard size affect earnings per share of commercial banks in Nigeria?

2. To what extent does ownership concentrationaffectearnings per share of commercial banks in Nigeria? 
3. To what extent do board meetings affectearnings per share ofcommercialbanks in Nigeria?

\subsection{Statement of the Hypotheses}

The following null hypotheses were formulated for the study:

1. Ho: Board size does not significantly affect earnings per share ofcommercialbanks in Nigeria.

2. Ho: Ownership concentration does not significantly affectearnings per share of commercial banks in Nigeria.

3. Ho: Board meetings do not significantly affect earnings per share of commercial banks in Nigeria.

\section{Literature Review}

\subsection{Theoretical Review}

However, for the purpose of this study, Agency Theory and Stewardship Theory were considered but eventually anchored on stewardship theory.

\subsubsection{Agency Theory}

Agency theory has undoubtedly dominated other theories as the most preferred approach to corporate governance studies [11-16]. Agency relationship is defined as "a contract under which one or more persons (the principal) engage another person (the agent) to perform some services on their behalf which involves delegating some decision-making authority to the agent" [17]. According to agency model, the separation of ownership and control creates an inherent conflict of interest between the shareholders (Principal) and the management (Agent) [11]. Although managers are said to be rational, but cannot be trusted to remain faithful by always acting in the best interest of the principal since they are also presumed to be self-interested $[18,19]$. Therefore, managers must be controlled to avoid "moral hazard" using some riskbearing and monitoring mechanisms that checkmate their deviant behaviours $[20,21]$. In order to effectively address the agency problem, the theorists acknowledged the crucial role of board as an instrument of owners in subduing the opportunistic behaviour of managers [22]. Agency theory advocated for a clear separation between decision management and control [20].

\subsubsection{Stewardship Theory}

The stewardship theory took an opposite view of management $[15,23,24]$. While agency theory hypothesised that managers are self-interested, the stewardship theory advanced that indeed managers can be trustworthy and thus not enticed by the extrinsic value but rather intrinsically motivated by desire for accomplishment, acknowledgment, self-actualization, self fulfilment, power, and affiliation. The theory recommends unification of the position of CEO and board chair to reduce agency costs and promote unity of command doctrine. One of the most viable paths to achieving board effectiveness and performance variation is conditioned on degree of board dependency with greater executive directors' involvement. By privilege the executive directors are presumed to have perfect information about the workings of the firm and therefore more suitable to play monitoring and control role as against the outsiders who might not possess the requisite knowledge and expertise required to perform the task [22-26].

\subsection{Empirical Review}

\subsubsection{Board Size and Earnings Management}

Klein found that firms with boards and/or audit committees composed of independent directors are less likely to have large earnings management [27]. The study also suggests that boards structured to be more independent of the CEO may be more effective in monitoring the corporate financial accounting process.

Ghosh, Marra and Moon reported that earnings management does not vary with board composition and structure, or with audit committee composition, expertise, and ownership [28]. In contrast, board size and audit committeesize, activity, and tenure are associated with earnings management.

Abed, Al-Attar, and Suwaidan found thatthe size of board of directors is the only variable among the existence of independence memberswithin the board of directors, the size of the board of directors, the role duality (CEO/chairman), the percentage of insider ownership that has a significant relation with earnings management [29].

Amarneh examined the effect of ownership structure and corporate governance on banks performance and found that large board size increases banks performance [30]. The study also shows that CEO duality is not important for Jordanian banks. Foreign ownership was also found to positively affect bank performance, thus suggesting that good corporate governancestandards are imperative to every bank and important to investors and other stakeholders.

Owolabi, Titilayo and Olanrewaju in their study investigated corporate governance and banks' profitability using panel regression analysis method [31]. They found that composition, Capital adequacy, Director Shareholding, Board Size and Audit committee demonstrated significance effect on banks' profitability.

\subsubsection{Ownership Concentration and Earnings Management}

Liu, Harris and Omar suggested that independence of audit committee, the frequency of meetings and thepresence of nomination committee are negatively related to earnings management [32]. However, theindependence of the board and firm size are positively related to earnings management.

Swastika's results showed a significant and negative relationship between audit qualityand firm size on one hand and earnings management on the other, a significant and positiverelationship between board of director and earnings management [33].

González and García-Meca reported that management ownership, ownership concentration, board activity and boardsize have a negative relationship with earnings 
management measured by discretionary accruals [34]. However, they did not find any statistically significant relation between family ownership, institutional ownership, CEO duality, and the absolute value of discretionary accruals.

Jegede, Akinlabi and Soyebo examined the corporate governance implication for banks performance in Nigeria [35]. Secondary source was used in gathering the data required for the research work. A regression analysis of the latent variables was adopted to examine the impact of corporate governance on bank performance. The results of the study showed that board size is statistically significant to bank performance while bank age and board committee have negative effect on bank performance.

Ehikioya examined the link between the structure of corporate governance and firm performance in Nigeria and found a higher level of ownership concentration leads to a higher market valuation [36]. The investigation shows that when major shareholdings are acquired in a firm, control cannot easily be disputed and the resulting concentration of ownership may lower the agency costs.

\subsubsection{Board Meetingsand Earnings Management}

Iraya et al found that earnings management is negatively related to ownershipconcentration, board size and board independence but positively related to board activity andCEO duality [37].

Furthermore, Patrick et al findings show that corporate governancepractices such as the board size, firm size, board independence, and strength of the auditcommittee have significant influence on earnings management practices [38].

Based on a meta-analysis of the relationship between concentrated ownership and firm financial performance in Asia, at the cross-national level of analysis, Heugens et al find a small but significant positive association between both variables [39]. This finding suggests that in regions with less than perfect legal protection of minority shareholders, ownership concentration is an efficient corporate governance strategy.

Busta stated that there exists a significant relationship between ownership concentration and performance, which is influenced by the tradition of the legal system [40]. The findings suggest an increase in concentration might be beneficial for banking firms in Continental Europe, where the degree of legal protection of minority investors is lower as compared to common law countries [40].

Mohammed and Wajdi considered the impact of corporate governance on the performance of banks in Nigeria [41]. The study made use of secondary data obtained from the financial reports of nine (9) banks for a period of ten (10) years (20012010). Data were analyzed using multiple regression analysis The study supported the hypothesis that corporate governance positively affects performance of banks. In conclusion, the study shows that poor asset quality (defined as the ratio of non-performing loan to credit) and loan deposit ratios negatively affect financial performance and vice visa.

Onakoya, Ofoegbu and Fasanyaexamined the impact of corporate governance on banks performance in Nigeria and found that lack of good corporate governance has resulted in the lack of confidence by investors which has negatively impacted the performance of these banks [42].

\subsubsection{Summary of Empirical Review}

Table 1. Summary of Empirical Review.

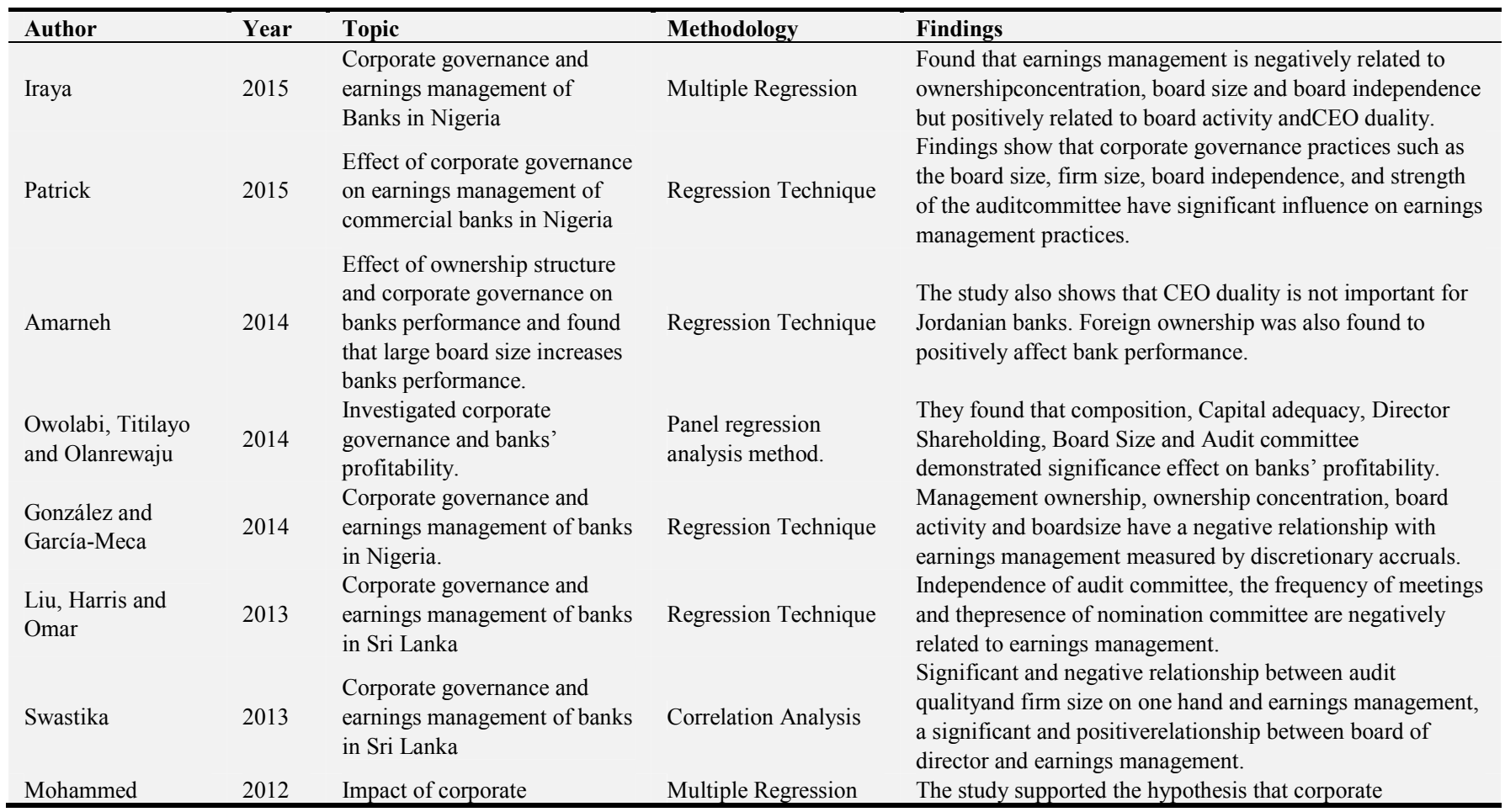




\begin{tabular}{|c|c|c|c|c|}
\hline Author & Year & Topic & Methodology & Findings \\
\hline & & $\begin{array}{l}\text { governance on the } \\
\text { performance of banks in } \\
\text { Nigeria. }\end{array}$ & Analysis & governance positively affects performance of banks. \\
\hline $\begin{array}{l}\text { Younas, Mahmood } \\
\text { and Saeed }\end{array}$ & 2012 & $\begin{array}{l}\text { Relationship between } \\
\text { corporate governance and } \\
\text { financial performance. }\end{array}$ & $\begin{array}{l}\text { Pearson Correlation } \\
\text { Analysis }\end{array}$ & $\begin{array}{l}\text { Prior year firm's performance has positive relationship with } \\
\text { board size but negative relationship with audit expenditure. }\end{array}$ \\
\hline $\begin{array}{l}\text { Onakoya, Ofoegbu } \\
\text { and Fasanya }\end{array}$ & 2012 & $\begin{array}{l}\text { Impact of corporate } \\
\text { governance on banks } \\
\text { performance in Nigeria }\end{array}$ & Multiple Regression & $\begin{array}{l}\text { Lack of good corporate governance has resulted in the lack } \\
\text { of confidence by investors which has negatively impacted } \\
\text { the performance of these banks. }\end{array}$ \\
\hline
\end{tabular}

Source: Author's Compilation, 2018.

The foregoing empirical reviews reveal that numerous works have been done on corporate governance of banks. However, most of these studies measured corporate governance and profitability of banks in Nigeria [31, 35, 41, 42], The period studied in these previous studies were limited to 2014. Consequently, this study will evaluate the effect of corporate governance on earnings management of banks in Nigeria, extending the period of corporate governance evaluation to 2017.

\section{Methodology}

The research was conducted in Nigeria; in the commercial banking sector of the economy with twenty one publicly quoted banks on the Nigeria Stock Exchange as at $31^{\text {st }}$ December, 2017, with available and sufficient data for analysis.

This research work adopted the approaches of Pulic; Williams and Firer; Chen, Cheng and Hwang; and Ahangar in the studies [43-46]. The research therefore, made use of secondary data, upon which time series data from 2008 to 2017) were extracted from the annual report and accounts of the sampled banks.

The population of the study is all the twenty one banks that operate in the Nigeria banking industry that are listed on the Nigeria Stock Exchange at the end of 2007.

The study made use of four (4) banks that will provide the necessary and required data for the study from 2008 to 2017. The selection technique was based on judgmental sampling technique, with success in data search a benchmark. The researcher selected the following banks: First Bank of Nigeria Plc, Zenith Bank Plc, Diamond Bank Plc and United Bank for Africa.

The study adopted multiple regression model which is shown as follows:

$$
\begin{gathered}
\text { EPSt }=\beta o+\beta 1 \text { BSIZEt }+\varepsilon t \\
\text { EPSt }=\beta o+\beta 10 \text { WNCONt }+\varepsilon t \\
\text { EPSt }=\beta o+\beta 1 \text { BMTt }+\varepsilon t
\end{gathered}
$$

The composite multiple regression (prediction) model is statistically formulated as:

$$
\text { EPSt } i=\beta o+\beta 1 B D S I Z E t+\beta 20 W N C O N t+\beta 3 B M T N t+\varepsilon t
$$

Where,

EPS: Earnings per share

BDSIZE: Board Size

OWNCON: Ownership Concentration

BMTN: Board Meeting

$\varepsilon$ : Stochastic disturbance (Error) Term

$\beta o$ : Coefficient (constant) to be estimated

$\beta i-\beta 6$ : Parameters of the independent variables to be estimated

t: Current period

\section{Data Presentation}

\subsection{Average Values of all the Focal Variables of the Banks Sampled}

Table 2. Average Values of all the Focal Variables of the Banks Sampled.

\begin{tabular}{lllll}
\hline YEARS & BDSIZE (No.) & BMTN (No.) & OWNCON \% & EPS \\
\hline 2008 & 14 & 7 & 46.39 & 4.55 \\
2009 & 14 & 7 & 36.13 & 4.24 \\
\hline
\end{tabular}

\begin{tabular}{lllll}
\hline YEARS & BDSIZE (No.) & BMTN (No.) & OWNCON \% & EPS \\
\hline 2010 & 14 & 7 & 37.3 & 3.93 \\
2011 & 16 & 7 & 51.43 & 3.62 \\
2012 & 15 & 7 & 51.29 & 3.3 \\
2013 & 14 & 8 & 48.51 & 2.99 \\
2014 & 14 & 8 & 45.72 & 2.68 \\
2015 & 15 & 8 & 42.94 & 2.37 \\
2016 & 15 & 9 & 40.16 & 2.11 \\
2017 & 15 & 8 & 41.55 & 2.24 \\
\hline
\end{tabular}

Source: Annual Report and Accounts of Sampled firms.

\subsection{Data Analysis}

From Figure 1 it could be observed that EPS moves in opposite direction with BMTN. This implies that as number of board meetings increases, earnings management will decrease, vice versa. This is the case with EPS and BDSIZE. EPS and OWNCON have similar pattern of movement except in 2009 and 2010 where they shared opposing movement pattern. 
LOG(EPS)

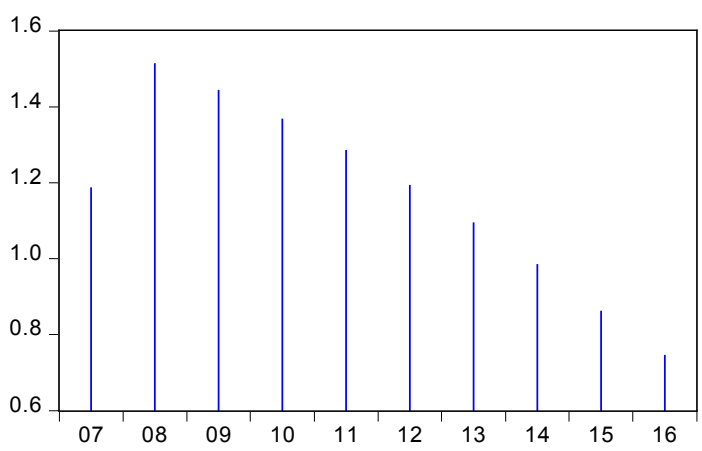

LOG(BMTN)

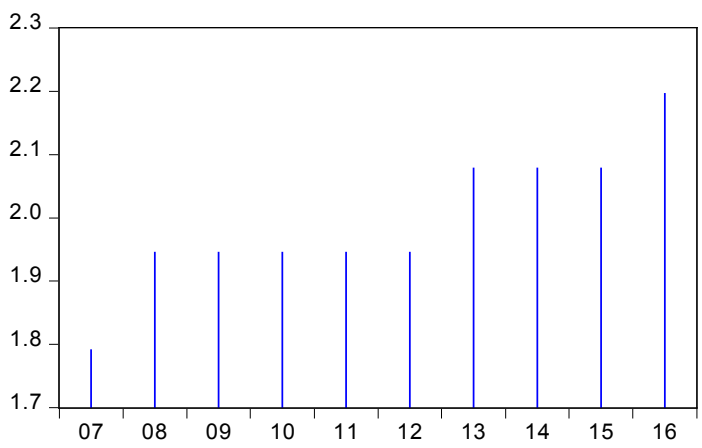

LOG(BDSIZE)

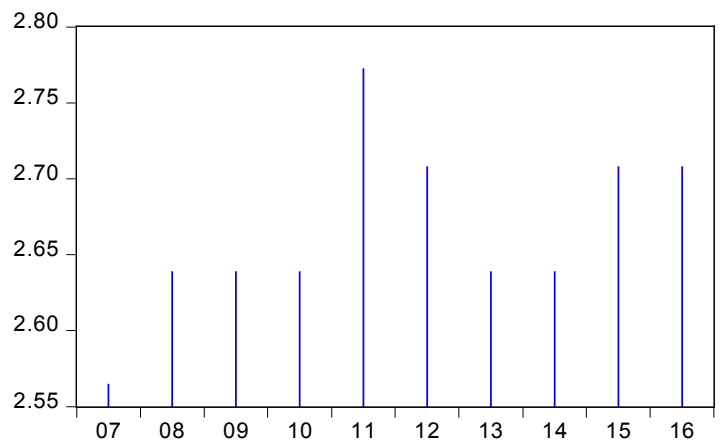

LOG(OWNCON)

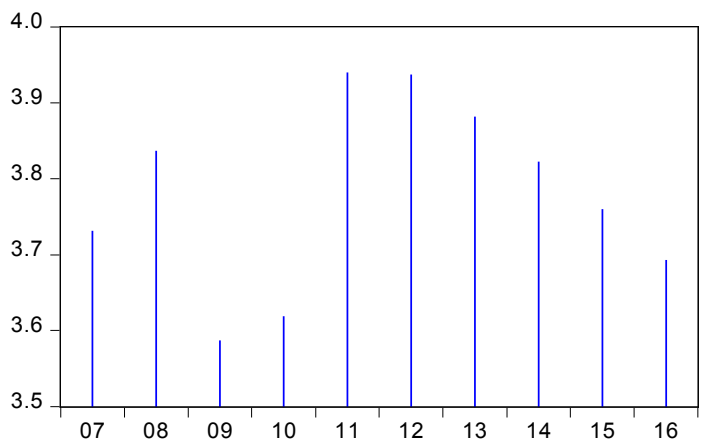

Figure 1. Spike Graph for the Focal Variables.

Eviews 10.0 Software

EPS: Earnings per share

BDSIZE: Board Size

OWNCON: Ownership Concentration

BMTN: Board Meeting

\subsubsection{Descriptive Statistic}

Table 3 depicts that all the variables under study are normally distributed. This was justified by the skewness figures of the variables that are less than one. More also the kurtosis coefficient of all the variables under study is less than three. The Jaque-Bera probability also justified the normality of the time series data by the insignificant result for all the variables.

Table 3. Descriptive Statistic.

\begin{tabular}{|c|c|c|c|c|}
\hline & LOG(EPS) & LOG(BDSIZE) & LOG(BMTN) & LOG(OWNCON) \\
\hline Mean & 1.168724 & 2.665698 & 1.995686 & 3.780912 \\
\hline Median & 1.190883 & 2.639057 & 1.945910 & 3.791170 \\
\hline Maximum & 1.515127 & 2.772589 & 2.197225 & 3.940222 \\
\hline Minimum & 0.746688 & 2.564949 & 1.791759 & 3.587124 \\
\hline Std. Dev. & 0.249758 & 0.058220 & 0.113351 & 0.124452 \\
\hline Skewness & -0.286357 & 0.197089 & 0.068483 & -0.193186 \\
\hline Kurtosis & 2.017863 & 2.640724 & 2.660448 & 1.814482 \\
\hline Probability & 0.763921 & 0.942460 & 0.972458 & 0.723320 \\
\hline Sum & 11.68724 & 26.65698 & 19.95686 & 37.80912 \\
\hline Sum Sq. Dev. & 0.561413 & 0.030506 & 0.115637 & 0.139396 \\
\hline Observations & 11 & 11 & 11 & 11 \\
\hline
\end{tabular}

Source: Eviews 10.0 Software.

EPS: Earnings per share

BDSIZE: Board Size

OWNCON: Ownership Concentration

BMTN: Board Meeting 


\subsubsection{Correlation Analysis Result}

Table 4. Correlation Analysis Result.

\begin{tabular}{lllll}
\hline & LOG(EPS) & LOG(BDSIZE) & LOG(BMTN) & LOG(OWNCON) \\
\hline LOG(EPS) & 1.000000 & -0.261126 & -0.722470 & -0.057271 \\
LOG(BDSIZE) & -0.261126 & 1.000000 & 0.416124 & 0.432879 \\
LOG(BMTN) & -0.722470 & 0.416124 & 1.000000 & 0.013716 \\
LOG(OWNCON) & -0.057271 & 0.432879 & 0.013716 & 1.000000 \\
\hline
\end{tabular}

Source: Eviews 10.0 Software.

EPS: Earnings per share

BDSIZE: Board Size

OWNCON: Ownership Concentration

BMTN: Board Meeting

This reveals that all the variables under study have negative relationship with earnings management of commercial banks in Nigeria. Board meeting is the only variable among the three variables that has strong relationship with earnings per share. Board size and ownership concentration both have weak relationship with share price. Such is the outcome of correlation analysis of commercial banks in Nigeria.

\subsubsection{Regression Analysis Result}

The multiple regression analysis result shows that board meeting and ownership concentration have positive effect on earnings per share of commercial banks in Nigeria. Meanwhile board size affects earnings per share negatively. The extent of effect board size and board meeting have on earnings per share are significant. The adjusted R-squared suggests that only about $66 \%$ of changes in earnings per share could be explained by the independent variables (board size, board meeting and ownership concentration). The Durbin-Watson stat result implies that there is no serial autocorrelation in the time series data because it is not more than 2 even in approximation.

Table 5. Regression Analysis Result.

\begin{tabular}{|c|c|c|c|c|}
\hline \multicolumn{5}{|c|}{ Dependent Variable: LOG(EPS) } \\
\hline Variable & Coefficient & Std. Error & t-Statistic & Prob. \\
\hline LOG(BDSIZE) & -0.397793 & 1.496190 & 3.265871 & 0.0092 \\
\hline LOG(BMTN) & 1.674280 & 0.692807 & -2.416661 & 0.0421 \\
\hline LOG(OWNCON) & 0.174575 & 0.636508 & -0.274269 & 0.7931 \\
\hline $\mathrm{C}$ & 4.109716 & 3.305758 & 1.243199 & 0.2602 \\
\hline R-squared & 0.729746 & \multicolumn{2}{|c|}{ Mean dependent var } & 1.168724 \\
\hline Adjusted R-squared & 0.664620 & \multicolumn{2}{|c|}{ S. D. dependent var } & 0.249758 \\
\hline S. E. of regression & 0.209764 & \multicolumn{2}{|c|}{ Akaike info criterion } & 0.003511 \\
\hline Sum squared resid & 0.264007 & \multicolumn{2}{|c|}{ Schwarz criterion } & 0.124545 \\
\hline Log likelihood & 3.982447 & \multicolumn{2}{|c|}{ Hannan-Quinn criter. } & -0.129263 \\
\hline F-statistic & 2.253025 & \multicolumn{2}{|c|}{ Durbin-Watson stat } & 1.606919 \\
\hline Prob(F-statistic) & 0.002588 & & & \\
\hline
\end{tabular}

Source: Eviews 10.0 Software.

EPS: Earnings per share

BDSIZE: Board Size

OWNCON: Ownership Concentration

BMTN: Board Meeting

\subsection{Test of Hypotheses}

Hypothesis One states that board size does not significantly relate to earnings per share of commercial banks in Nigeria.

Decision Rule: Reject $\mathrm{H}_{0}$ if $\mathrm{P}$-Value is less than a-value of 0.05 .

Decision: Table 5 reveals a P-Value of 0.0092 which is less than a-value of $0.05 ; \mathrm{H}_{0}$ is therefore rejected in respect to earnings per share of Nigeria banking sector. This implies that board size significantly affects earnings per share of commercial banks in Nigeria.

Hypothesis Two states that ownership concentration does not significantly relate to earnings per share of commercial banks in Nigeria.

Decision Rule: Reject $\mathrm{H}_{0}$ if P-Value is less than a-value of 0.05 .

Decision: Table 5 depicts a P-Value of 0.0421 which is less than a-value of $0.05 ; \mathrm{H}_{0}$ is therefore rejected in respect to earnings per share of Nigeria banking sector. This implies that ownership concentration significantly affects earnings per share of banks in Nigeria.

Hypothesis Three states that board meeting does not significantly relate to earnings per share of commercial banks in Nigeria.

Decision Rule: Reject $\mathrm{H}_{0}$ if P-Value is less than a-value of 0.05 .

Decision: Table 5 shows a P-Value of 0.7931 which is 
higher than a-value of $0.05 ; \mathrm{H}_{0}$ is therefore accepted in respect to earnings per share of Nigeria banking sector. This implies that board meeting does not significantly affect earnings per share of commercial banks in Nigeria.

\section{Discussion of Results}

Hypothesis one: This hypothesis states that board size does not significantly affect earnings per share of commercial banks in Nigeria. From the result of the regression analysis in Table 5, board size affects earnings per share negatively and significantly in the tune of 0.0092 . This is in tandem with the findings of Owolabi, Titilayo and Olanrewaju; Amarneh; Abed Al-Attar and Suwaidan; and Ghosh, Marra and Moon who also found significant effect between board size and earnings management [28-31].

Hypothesis two: This hypothesis states that ownership concentration does not significantly affect earnings per share of commercial banks in Nigeria. From the result of the regression analysis in Table 5, board size affects earnings per share positively and insignificantly in the tune of 0.7931 . This is in tandem with the findings of [26] who also found positive relationship between board size and earnings management.

Hypothesis three: This hypothesis states that board size does not significantly affect earnings per share of commercial banks in Nigeria. From the result of the regression analysis in Table 5, board meeting affects earnings per share positively and significantly in the tune of 0.0421. This is in tandem with the findings of Heugens, Essen, \&Oosterhout; and González and García-Mecawho also found significant and negative effect between board size and earnings management $[39,34]$.

\subsection{Summary of Findings}

Board size hasnegative and significant effect on earnings management of commercial banks in Nigeria.

Ownership concentration has a positive and insignificant effect on earnings management of commercial banks in Nigeria.

Board meeting has positive and significant effect on earnings management of commercial banks in Nigeria.

\subsection{Conclusion}

Banks are established for the sole purpose of generating earnings to the shareholders. Banks management usually thwart this goal with their selfish interest by using the earnings generated by banks for their own selfish purposes, leaving the fund owners empty handed. This poor corporate governance practices resulted to this study; to evaluate the relationship between corporate governance and earnings management of commercial banks in Nigeria.

The findings of the study show that board size negatively and significantly affect earnings management of commercial banks, while, ownership concentration affects earnings management positively and insignificantly. The effect board meeting exerts on earnings management is positive and significant. This implies that board meetings and board size have significant effect on earnings management, and can be used to check how well commercial banks manage their earnings in Nigeria.

\subsection{Recommendations}

Banks should be encouraged to maintain a reasonable board size. Too many board members will affect the decision making duration, and can decrease the effectiveness of the board. The number size should not exceed ten members.

Higher ownership concentration should be encouraged by Nigerian banks. This is because the higher the concentration of ownership, the more the management reduces the number of earnings misappropriations. This is because when ownership are split into many units, there will be investment laxity, enabling management the opportunity to misappropriate fund. If few people are owners, they will be more vigilant to ensure maximum return on investment.

Boards of Nigerian commercial banks should hold board meetings more often, because it is necessary in taking far reaching decisions that will move the bank forward.

\section{References}

[1] Sanusi L. (2009). An Assessment of Current Development in the Nigerian Economy and the Central Bank of Nigeria (CBN) Policy Action. A maiden briefing by the New CBN Governor, June 2009.

[2] Vasile Cocris \& Maria C. Ungurcanu (2007). Why are banks special? An approach from the corporate governance perspective. Scientific annals-at Cuza University of Lasi, Economics series, pp 55-66, 2007.

[3] Clarkson Max \&Deck Michael (1997): Effective governance for Microfinance Institutions. CGAP focus note: No 7, Washington DC; World Bank Group.

[4] Ofiafor E. \&Imoisili O (2010). Corporate governance and the entrepreneur, in F. C. Okafor: Entrepreneurship A practical approach, Benin City: Modern Publishing Company.

[5] Okafor F. O (2011). "50 years of Banking Sector Reforms in Nigeria, (1960-2010): past lessons and future imperatives" Enugu, Ezu books Nigeria Ltd.

[6] Adeola F (2003). Transparent and Accountable corporate governance in the capital market challenges for market operators and stakeholders, Nigerian stock market annual.

[7] Anya O. A. (2003). Corporate Governance as an effective tool for combating financial and Economic crimes. The Nigerian bankers. October-December.

[8] Wolfensohn J. (1997). Cited by Anya 2003. Corporate governance as an effective tool for combating financial and economic crimes. The Nigerian banker. October-December.

[9] Dyck A (2001). Privatisation and corporate governance: principles, evidence, future challenges. The World Bank Research Observer - Vol 16, No 1 (Spring 2001) pp. 59-84. 
[10] Shleifer A. \&Vishny R (1997). A survey of corporate governance. Journal of Financial Economics, 522; 737-783.

[11] Aguilera R, Filatotchev I, Gospel H \& Jackson G (2008). An organizational approach to comparative corporate governance: costs, contingencies and complementaries. Organization science. 19, 475-492. 10.2139/ssrn. 955043.

[12] Zahra S \& Pearce J. (1989). Boards of directors and corporate financial performance: a review of integrative model. Journal of management, 152; 291-334.

[13] Daily C, Dalton D \&Najagopalan N (2003). Governance through Ownership: centuries of practice, decades of research, Academy of Management Journal 46, 115-158.

[14] O'Sullivan, N. (2000). The determinants of non-executive representation on the boards of large UK companies. Journal of Management and Governance, 4, 283-297.

[15] Davis H, David S, Donaldson L. (1997). Toward a stewardship theory of management review. 22.20.10.2307/259223.

[16] Diwedi, N. and Jain A. (2002). Corporate Governance and Performance of Indian Firms: The Effect of Board Size and Ownership. Review of Economics and Statistics, February, 104-107.

[17] Jensen M, Meckling W. (1976): A theory of the firm: Governance, Residual Claims and Organizational forms, Harvard University Press. December 2000. Journal of Financial Economics (JFE). Vol 3, no 4, 1976.

[18] Williamson Oliver E (1975). Markets and Hierarchies: Analysis and Antitrust Implications; A study in the economics of internal Organization. University of Illinois at Urbana. Champaign's Academy for Entrepreneurial Leadership Historical Research.

[19] Padilla A (2002). Can Agency theory justify the regulation of Insider Trading. Quarterly Journal Austrian Economics. (202) 5: 3 .

[20] Jensen M, Fama E (1983). Foundation of Organizational Strategy. Harvard University Press 1998; Journal on Law and Economics, Vol. 26 June 1983.

[21] Filatachev I., Jackson G., Gospel H., Allcock D. (2007). Key Drivers of "Good" Corporate governance and the appropriateness of UK Policy Responses, London: Dept of Trade and Industry.

[22] Stiles P., \& Taylor B. (2001). Boards at work: how directors view their roles and responsibilities, Oxford University Press.

[23] Donaldson L., Davis J. (1991). 'Stewardship Theory or Agency Theory.' CEO governance and Shareholder Returns, Australian Journal of Management, 16, 1, 49-64.

[24] Donaldson L., Muth M. (1998). Stewardship Theory and Board Structure: a contingency Approach, corporate governance, 6, 1, 5-28.

[25] Nicholson G., Kiel G (2007). Corporate governance: an international review, vol. 15, 4, pp 585-608, July 2007.

[26] Helmer H. W (1996). A director's role in strategy. Directors and Boards, 20 (3) 22-25.

[27] Klein, A., (2002). Audit committee, board of director characteristics, and earnings management. Journal of Accounting and Economics, 33 (3), 375-400.

[28] Ghosh A. and D. Moon (2010). Corporate Debt Financing and Earnings Quality, journal of business finance \& accounting, 37, (2010), 538-559.

[29] Abed, Suzan; Al-Attar, Ali; Suwaidan, Mishiel (2012). "Corporate Governance and Earnings Management: Jordanian Evidence". International Business Research Vol. 5, No. 1; January.

[30] Al-Amarneh, A. (2014). Corporate governance ownership structure and bank performance in Jordan. International Journal of Economics and Finance, 6 (6), 192-202.

[31] Owolabi, S. A., Owolabi, T. J. \&Olanrewaju, G. O. (2014). Corporate Governance and Banks' Profitability: An Assessment of Post Consolidation Period (2006-2010). Unique Journal of Business Management Research. Vol. 2, No. 1: 1-16.

[32] Liu, J., Harris, H., andOma, N., (2013). Board committees and earnings management. Corporate Board: Role, Duties \& Composition/Volume 9, Issue 1.

[33] Swastika D. L. The (2013). Corporate Governance, firm size and earnings management. Evidence in Indonesia Stock Exchange. IOSR Journal of Economics and Finance (IOSRJEF) $10(4) ; 77-82$.

[34] González, J. S., \& García-Meca, E. (2014). Does corporate governance influence earnings management in Latin American markets? Journal of Business Ethics, 121 (3), 419440.

[35] Jegede, C. A., Akinlabi, B. H. and Soyebo, Y. A. (2013). Corporate Governance Efficiency and Bank Performance in Nigeria. World Journal of Social Sciences, 3 (1): 178 - 192.

[36] Ehikioya, B. I. (2009). Corporate governance structure and firm performance in developing economies: Evidence from Nigeria. Corporate Governance, 9 (3), 231-243.

[37] Iraya, C. Mwangi, M. \&Wanjohi, G. (2014). The effect of corporate governance practices on earnings management of companies listed at the Nairobi securities exchange, European Scientific Journal January 2015 edition Volume 11, No 1.

[38] Patrick E, Paulinus E, Nympha A (2015). The influence of corporate governance on Earnings Management practices: a study of some selected quoted companies in Nigeria. American journal of Economics, Finance and Management. Vol. 1, No 5, pp 482-493.

[39] Heugens, P. P., Essen, M., and Oosterhout, J. (2008). Metaanalyzing ownership concentration and firm performance in Asia: Towards a more fine grained understanding. Asia Pacific Journal of Management, 26 (3), 481-512.

[40] Busta, I. (2008). Corporate Governance in Banking - A European Study. Business. Mohammed, F. (2012). Impact of corporate governance on banks performance in Nigeria. Journal of Emerging Trends in Economics and Management Sciences, 3 (3).

[41] Mohammed F, Wajdi Ben R. (2012). The impact of Good corporate Governance practices on Stakeholder's satisfaction in Tunisian listed companies. (Oct 20, 2012) International Journal of Business as Management Studies, Vol 4, 2, 2012. 
[42] Onakoya A, Ofoegbu D, Fasanya I (2012). Corporate governance and Bank Performance: A pooled study of selected Banks in Nigeria.

[43] Pulic A. (1998). "Measuring the performance of Intellectual potential in knowledge economy" paper presented at the 2nd McMaster Word Congress in Measuring and Managing Intellectual Capital by the Austria team for Intellectual Potential.

[44] Firer S, Williams M. (2003). Intellectual Capital and traditional measures of corporate performance - Journal of Intellectual Capital. Vol 4, issue 3, pp. 348-360.

[45] Chen M. C., Cheng S. J., Hwang Y (2005). An empirical Investigation of the relationship between Intellectual Capital and Firms market value and financial performance. Journal of Intellectual Capital, Vol. 6, No 2, pp. 159-176.

[46] Ahangar R (2011). The relationship between Intellectual Capital and Financial Performance: An empirical investigation in an Iranian company. African Journal of Business Management. Vol 5 (1) pp 88-95.

[47] Chiang, N. (2005). An Empirical study of corporate governance and corporate performance, Journal of American Academy of Business, Cambridge.

[48] Fischer M., RosenzweigK., (1995). Attitudes of Students and Accounting Practitioners Concerning theEthical Acceptability of Earnings Management, Journal of Business Ethics, volume 14 , issue 6, pp. 433-444.

[49] Hijazi, Q \& Al-Thuneibat, A. 2015, Auditor's opinions and earnings management: evidence from Jordan, Proceedingsof The Third International Conference on Innovation Economy, University of Jordan, Amman, Jordan, 14-15 April, 2015.

[50] Kirkbride J. B., Fearon P., Morgan C., Dazzan P., Morgan K., Murray R. M., Jones P. B. (2007). Neighbourhood variation in the incidence of psychotic disorders in Southeast London. Social Psychiatry and Psychiatric Epidemiology. 2007; 42 (6): 438-445.

[51] La Porta R. Lopez-De-SilanesF., and Shleifer A. (1999). Corporate ownership around the world. The Journal of Finance 54 (2), April 1999.
[52] Laing, D., and Weir, C. M. (1999). Governance structures, size and corporate performance in UK Firms. Management Decision, 37 (5), 457-464.

[53] Lefort, F., and Urzua, F. (2008). Board independence, firm performance and ownershipconcentration: Evidence from Chile. Journal of Business Research, 61 (6), 615-622.

[54] Lipton, M., and Lorsch, J. (1992). A Modest Proposal for Improved Corporate Governance. Business Lawyer, 48 (1), 59-67.

[55] Lopez, F., Azofra, V., and De Andres, P. (2005). Corporate boards in OECD Countries: Size, composition, functioning, and effectiveness. Corporate Governance: An International Review, 13 (2), 197-210.

[56] Oman, C. P. (2001), Corporate Governance and National Development, OECD Development Centre, Working Paper No. 180, Research programme on: Corporate Governance in Developing Countries and Emerging Economies.

[57] Onakoya, A. B. (2013). Stock Market Volatility and Economic Growth in Nigeria (1980-2010), International Review of Management and Business Research, 2 (1), 201 209.

[58] Owusu-Ansah S. (1998). The Impact of Corporate Attributes on the Extent of Mandatory Disclosure and Reporting by Listed Companies in Zimbabwe. The International Journal of Accounting, 33 (5).

[59] Paul M. Healy and James M. Wahlen (1999) A Review of the Earnings Management Literature and Its Implications for Standard Setting. Accounting Horizons: December 1999, Vol. 13, No. 4, pp. 365-383.

[60] Shivdasani, A., and Zenner, M. (2002). Best Practices in Corporate Governance:What two decades of research work. New York: Salomon Smith Barney.

[61] Yermack, D. (1996). Higher market valuation of companies with a small board of directors. Journal of Financial Economics, 40 (2), 185-211. 